\title{
FABRICATION OF ICHIRO NINE-CELL CAVITIES IN PAL FOR STF OF KEK*
}

\author{
I.S. Park ${ }^{\#}$, Y.U. Sohn, J.H. Choi, M.S. Hong, H.C. Kwon, W.H. Hwang, D.T. Kim, Y.C. Kim, \\ C.W. Chung, J.Y. Hung, I.S. Ko, PAL, POSTECH, Pohang, Korea \\ S.H. Kim, S.U. Kim, S.S. Song, Welding Research Center, RIST, Pohang, Korea
}

\section{Abstract}

Pohang Accelerator Laboratory, POSTECH have studied SRF cavity and constructed SRF test laboratory from January 2006. The first activity for SRF research was to develop SRF $3^{\text {rd }}$ harmonic cavity for PLS, which cavity was done in 2006 and the cryostat are under design. The fabrication of ICHIRO cavity, which is ILC ACD cavity, is PAL's second activity related to SRF. Deep drawing, trimming and welding by electron beam for a 9-cell ICHIRO cavity were done in PAL. The polishing processes of RF surface including electropolishing were done in KEK with collaboration. This will be tested with real beam in STF-1 of KEK in second half period of 2007. This paper reports fabrication of ICHIRO nine-cell cavities in PAL.

\section{INTRODUCTION}

Superconducting 9-cell RF cavity, which is ILC ACD SRF cavity designed KEK (so called ICHIRO cavity), was fabricated in PAL to train manpower and to contribute in ILC R\&D activities. The processes of fabrication such as designing, fabrication and welding of dies, jigs and cavity were done PAL-self with advices from KEK. This paper reports fabrication processes of 9cell SRF cavity in PAL. This cavity will be installed in Superconducting Test Facility (STF in KEK) in 2007.

\section{SHAPE OF CAVITY}

ICHIRO 9-cell cavity was designed in KEK with modification of low loss cavity. It is expected that maximum $\mathrm{E}_{\text {acc }}$ can be reached to $51 \mathrm{MV} / \mathrm{m}$, computation limit, with well-prepared RF surface. The fabricated cavity is the second version of ICHIRO type, in which end group of cavity including beam pipe was improved to reduce intensity of HOMs. Figure 1 shows cavity profile of mid-cell.

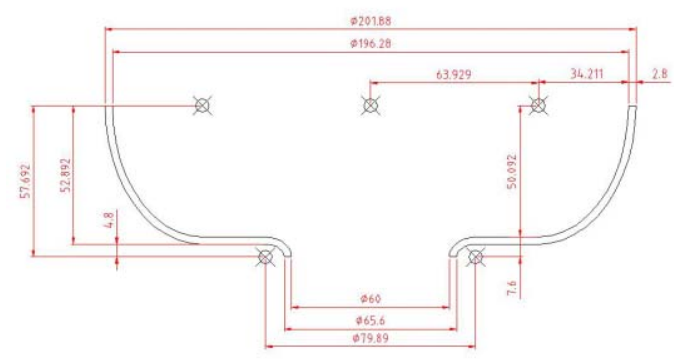

Figure 1: Layout of half-cell

\footnotetext{
*Work supported by KMAC
}

${ }^{*}$ rf2@postech.ac.kr

\section{MANUFACTURE OF HALF-CELL}

\section{Material}

For cavity cells $\mathrm{Nb}$ discs with RRR 200 were provided from Tokyo Denkai, Japan, of which diameter and thickness were $260 \mathrm{~mm}$ and $2.8 \mathrm{~mm}$. The thickness deviations from specification were $-50 \mu \mathrm{m}$ to $20 \mu \mathrm{m}$. The stiffening ring to reduce deformation of 9-cell cavity was made with $\mathrm{Nb}$ sheet, its thickness is $3.0 \mathrm{~mm}$.

\section{Deep Drawing}

To produce exact shape of half-cell cavity 2 sets pressing dies were fabricated with trial and error. Also several times of shape correction were tried. As shown in Figure 1 half-cell has straight section, which was trouble maker by spring-back. Through shaping press dies and adjusting pressing parameters and procedure proper halfcell cavities were obtained. Table 1 show dimensional error of press dies that it was used to press half-cell.

Table 1: Profile error of press $\operatorname{die}(\mu \mathrm{m})$

\begin{tabular}{|c|c|c|c|c|c|c|}
\hline & \multicolumn{2}{|c|}{ Equator } & \multicolumn{2}{c|}{ Straight } & \multicolumn{2}{c|}{ Iris } \\
\cline { 2 - 7 } & Max & Min & Max & Min & Max & Min \\
\hline Female Die & 96 & -2 & 24 & -20 & 43 & -136 \\
\hline Male Die & 15 & -35 & 20 & -6 & 6 & -110 \\
\hline
\end{tabular}

During the trial pressing, there was air exploding because air was compressed between shaped $\mathrm{Nb}$ cell and female die. This compressed air resisted full-shaping half cell so that half cell could not have design shape. This problem was resolved by making venting holes in female die. Figure 2 shows pressing dies.
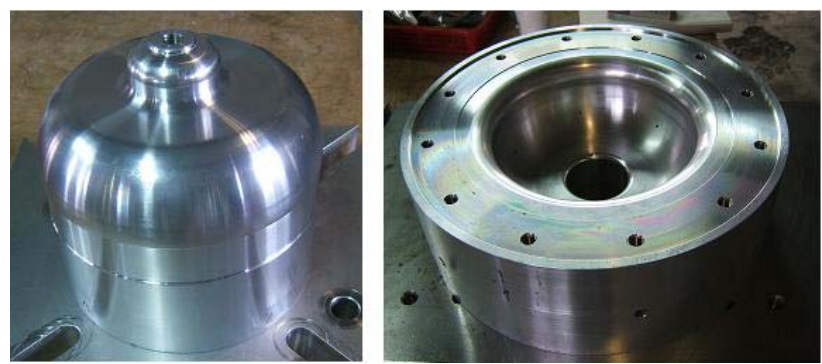

Figure 2: Male \& Female die

The pressing condition and procedure such as pressure of shaping, stroke of male die, pressing speed and final pressing time were also import factor to get correct cell shape. Our condition of pressing was follows:

- Stroke pressure: $16 \mathrm{Mpa}$

- Static pressure after finishing stroke: $16 \mathrm{Mpa}$ 
- Duration of static pressure: $60 \mathrm{sec}$

Trimming, post process of deep drawing was used for checking exactness of pressed half-cells. Trimming length was decided with consideration of thermal contraction in parts of equator and iris during electron beam welding. It was also obtained through test welding with trial cavity and through KEK advice. The optimal trimming length was:

- Length of equator part : $0.15 \mathrm{~mm}$

- Length of iris part : $0.07 \mathrm{~mm}$

Figure 3 shows setting pressed half-cell in trimming jig, in which half-cell is test cell with copper disc.

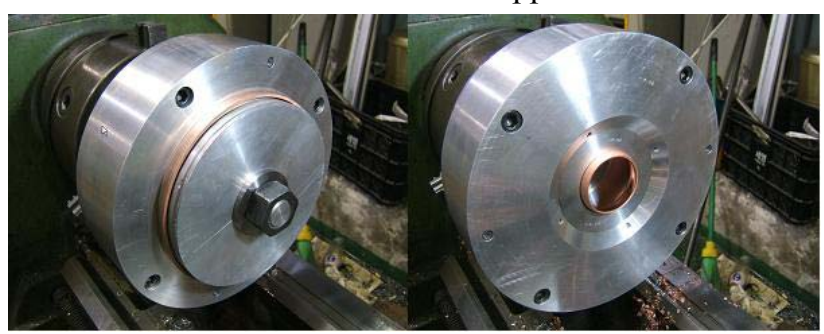

Figure 3: Setting trimming in lathe

\section{Checking Cell Profile with CMM}

To confirm design profiles of half-cell, deviations of profile against design for all half-cell cavities were checked with 3-dimensional measuring machine. Although errors from every process of fabrication, surface preparation and operation in cold environment are accumulated, each process must have its own reasonable errors. It is hard to know that what level of shape error is allowable. Some experiences, error estimation from computation and measured data gives clue to determine error level. Table 2 shows profile errors against design

Table 2: A profile error of half-cell

\begin{tabular}{|c|c|c|}
\hline & $\operatorname{Max}(\mu \mathrm{m})$ & $-\operatorname{Max}(\mu \mathrm{m})$ \\
\hline Inner Surface & 426 & -331 \\
\hline Roundness of Iris & 26 & -25 \\
\hline Roundness of Equator & 78 & -78 \\
\hline Height of Half-Cell & 38.35 & -38.20 \\
\hline
\end{tabular}

\section{Checking Profile Uniformity between Cells with} Network Analyzer

Frequency of half-cell at room temperature is not so important, but it provides information for deviation of cell profile from design during fabrication and for cell uniformity after trimming. So it is helpful to decide half cells trimmed are proper or not.[1] The average frequency with 20 half cells for mid-cell of ICHIRO cavity was 1283.64 MHz (Design frequency: $1300 \mathrm{MHz}$ ) and standard deviation was $1.217 \mathrm{MHz}$. Figure 4 shows frequency checking device for half-cell cavities.

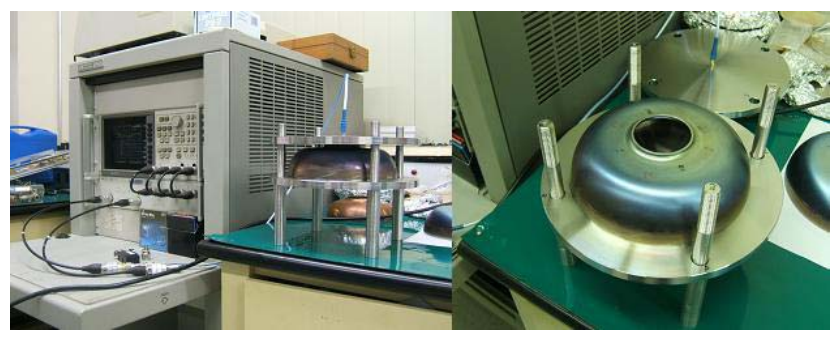

Figure 4: Frequency measurement of half-cell

\section{ELECTRONIC BEAM WELDING}

Due to high power density with focusing beam almost all SRF cavities for accelerator are fabricated with electron beam welding (EBW) in these days. In jointing half-cell and cell to cell, quality of welding bead is most important, especially in equator. Also there must not be void in welding parts. For welding quality, cells were polished with chemical acid to remove oil, oxidized layer, impurities and so on, contaminated during fabrication.[2] EBW for fabrication of 9 cell cavity was done following processes:

- Making dumbbells by jointing two half cells in iris

- Welding multi-full cell by joint dumbbells in equator

- Making end group with end cell and beam pipe

- Making 9-cell cavity by joint mid-full cell and end group

Before final welding, the optimal welding condition was found by studying welding parameters and analyzing welding specimen with electron microscope. With these conditions, dimension errors of cells, machining quality to be welded and shape of welding surfaces also effected welding quality.

\section{EBW of Dumbbells}

Welding dumbbells were done in series, outside of iris about $70 \%$ of depth, inside of iris about $40 \%$ then welding stiffening ring. The outer welding was main works, while inner one was for smoothening welding bead. Table 3 shows welding condition, but it is not rigid parameters, i.e. welding quality depends severely on worker's technique and experiences. Figure 5 shows dumbbells and its welding surfaces.

Table 3: Condition of dumbbells welding

\begin{tabular}{|c|c|c|c|}
\hline & Outer of Iris & Inner of Iris & Stiff Ring \\
\hline Current $(\mathrm{mA})$ & 27 & 25 & 15 \\
\hline Voltage(kV) & 130 & 130 & 130 \\
\hline Focusing & 890 & 890 & 890 \\
\hline Speed(mm/min) & 600 & 600 & 600 \\
\hline Angle(deg) & 90 & 55 & 70 \\
\hline
\end{tabular}




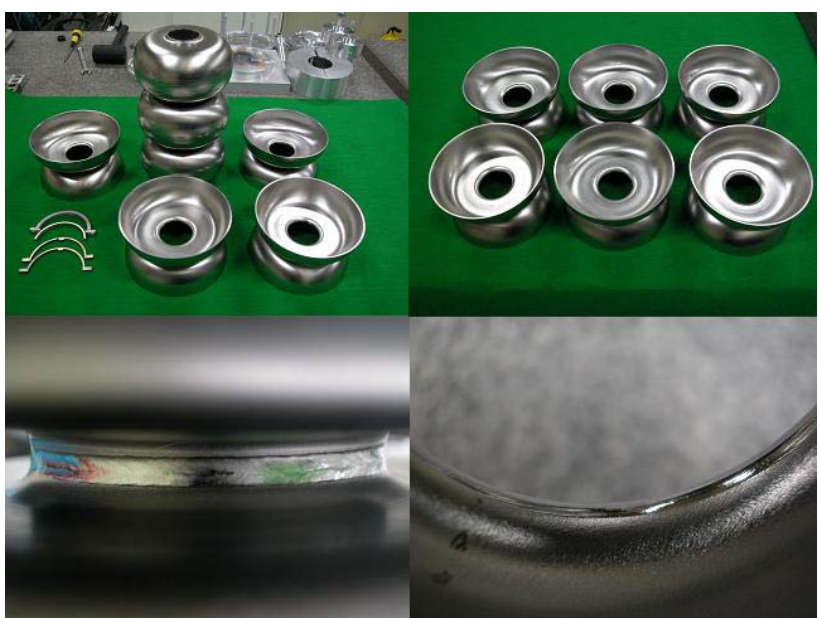

Figure 5: Welding surface of iris part

\section{EBW of 9-Cell Cavity}

Before welding 9-cell cavity, mechanical dimension tuning for all dumbbells were done to correct deformation from welding dumbbells. Also scratches on RF surfaces and sharp welding beads on iris were grinded out. Welding 9-cell cavity was done step by step with dumbbells and end group finally. In every step welding parted was investigated with naked-eye and dimension was checked. Then with results welding condition was adjusted slightly to get better joint parts. The welding condition of 9-cell cavity was;

- Voltage of accelerator : $120 \mathrm{kV}$

- Current of beam : $33.5 \mathrm{~mA}$

- Speed of welding : $10 \mathrm{~mm} / \mathrm{sec}$

- Focus of beam : Defocusing

- Wave pattern of beam : Triangle

Figure 6 shows process of mechanical tuning of dumbbell and installation of 9-cell welding. Figure 7 shows final 9-cell ICHIRO cavity.

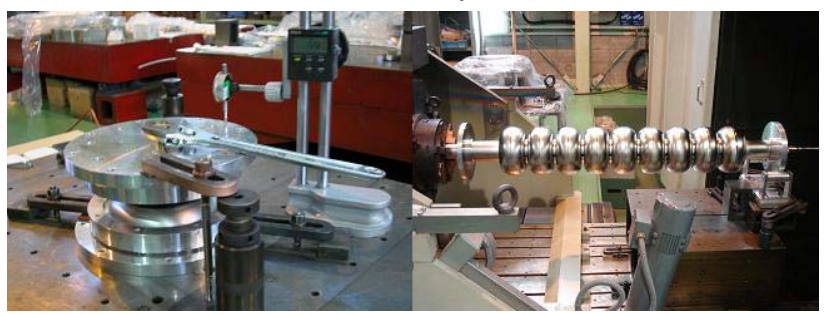

Figure 6: Mechanical tuning \& assembly of 9-cell cavity

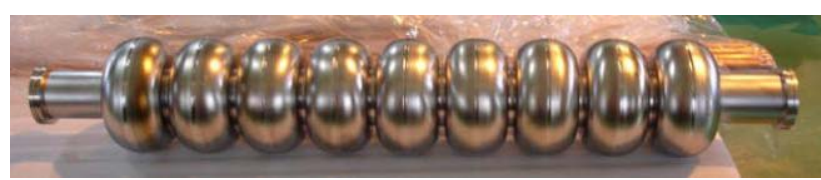

Figure 7: Final 9-cell ICHRO cavity after EBW

\section{RESULT \& PLAN}

PAL produced all dies, jigs and dumbbells including engineering design by ourselves, but welding 9-cell cavity was done in Japanese company with KEK's collaboration because no welding machine big enough for 9-cell cavity was available in Korea.

Now, the cavity is in processes of post surface preparation in KEK for vertical test (VT) as ILC S0 study. After VT straight pipe in end group will be replaced with beam pipe with HOM couplers and flanges for power coupler.

Fabrication of 9-cell SRF cavity is one of PAL's efforts to contribute in International Linear Collider (ILC). This cavity is for training manpower of PAL and will be installed STF in KEK to study ILC main Linac including cryomodule with cavity.

\section{ACKNOWLEDGMENT}

This work was funded by KMAC in Korea. Welding Centre in RIST provided EBW machine without limitation and advices. We appreciate these two organizations.

We appreciate also ILC Asia WG 5 in KEK (Leader: Kenji Saito) for advices and provision of information for ICHIRO cavity.

\section{REFERENCES}

[1] I.S. Park, Y.U. Sohn, etc "Prototype Development of SC $3^{\text {rd }}$ Harmonic RF Cavity for PAL", The Korea Institute of Applied Superconductivity and Cryogenics, October 2006.

[2] Y.U. Sohn, "Application of superconductivity engineering technique for high energy physics", The Korea Institute of Applied Superconductivity and Cryogenics, 8(2006)-1, p. 27-p34. 